\title{
Tourist Perceptions of Heritage Exhibits: A Comparative Study from Israel
}

\author{
Yaniv Poria \\ School of Management, Department of Hotel and Tourism \\ Management, Ben-Gurion University of the Negev, Beer-Sheva, Israel \\ Richard Butler \\ Strathclyde Business School, University of Strathclyde, 94 Cathedral \\ Street, Glasgow, G4 OLG, Scotland
}

\author{
David Airey \\ School of Management, University of Surrey, Guildford, GU2 7XH, \\ England
}

It is common in tourism and leisure literature to define and approach tourism subgroups in terms of the presence of the tourists in certain spaces. This approach is challenged in the present paper. It is argued that the understanding of heritage tourism should be based on the link between the individual and the space, namely tourist perceptions of a site relative to their own heritage. Based on a study dealing with visitation patterns to places where historic artefacts are presented, it is suggested that tourist perception is key to the understanding of visitation patterns. It is not so much the artefacts the tourists see or observe, but the meaning they ascribe to them. The theoretical implications of this argument are discussed in terms of tourism in general and heritage tourism in particular, as well as the practical applications to cultural heritage management.

Keywords: heritage, tourism, heritage tourism, perception, Israel

\section{Introduction}

Segmenting visitors by dividing the population into groups whose members present similar characteristics, needs and behaviours helps operators deal with the management of visitor attractions (Swarbrooke, 2002). The first stage in the segmentation process is dividing the market into distinct groups which require separate products or marketing mix (Kotler et al., 2003). In this paper an attempt is made to classify those who visited a heritage site into different groups. Such attempts have already been made in the heritage tourism literature and commonly emphasise the attributes of the site visited or the characteristics of the tourists. This paper attempts to highlight the links between the individual and the tourist. Specifically, tourists' perceptions of the site relative to their own heritage are examined as an element which can differentiate between visitors to heritage settings.

The link between the individual and the site has been mentioned in heritage management (e.g. Black, 2001; Howard, 2003) and museum literature (e.g. Hooper-Greenhill, 1994) to suggest that different visitors experience a heritage 
setting differently. However, a link has rarely been made to visitor behaviours of importance to the management of heritage attractions. Moreover, almost no attempt has been made to identify the link between the site and the heritage presented in a manner that helps us understand people's behaviour at heritage settings. This study attempts to explore whether tourist perceptions are important in understanding heritage tourism. Is it the artefact exhibits or the subjective meaning ascribed to them by the individuals observing them which is important?

Two lines of study were employed to investigate this concept. It is suggested that implementing these two lines of study will contribute to the validity of the findings and allow them to be generalised to other heritage settings. First, tourist visitation patterns at two heritage sites that differ significantly from each other were examined. In the context of these two sites, tourist behaviours before, during and after the visit were studied. Differences across such a time frame may provide the basis to argue that tourist perceptions of the heritage presented is at the heart of tourist behaviour. The second line of study was to investigate tourist decisions to visit different heritage sites located relatively close to each other. Differences found here would provide further justification for the idea that the meaning tourists ascribe to the object exhibits is at the centre of their behaviour. By integrating the findings from different lines of study in which a variety of aspects of tourist behaviours were explored, an attempt was made to gain a deeper understanding of tourist perceptions of the heritage relative to their own heritage as key to understanding tourist behaviours at heritage settings.

\section{Literature Review}

The way subgroups are identified and approached in tourism research has already been challenged. Poria et al. (2001) suggest that in the tourism literature it is common to define and discuss subgroups solely in terms of the presence of tourists or their activity in certain spaces or physical environments. This approach has two main effects. First, we come across many situations where the same activity could be classified under various tourism subgroups. A visit to a winery, for example, could be classified as industrial tourism, cultural tourism, heritage tourism, culinary tourism, wine tourism, etc. Secondly, a vast array of subgroups has emerged in tourism research. Poria et al. (2001), despite suggesting that it is easier to quantify tourism subgroups based on this approach (while noting that overlapping may occur), also point out that it has substantial disadvantages.

A review of the literature leads to the assumption that heritage tourism itself has been divided into further 'sub-subgroups'. Examples include the emergence of subgroups based on the attributes or location of the heritage in question. Thus a literature search reveals work on cultural heritage (Alzua et al., 1998; MacDonald \& Jolliffe, 2003), built heritage (Black, 1990), urban heritage (Chang et al., 1996; Gibson \& Hordman, 1998), natural heritage (Keller, 1999), industrial heritage (Edwards \& Coit, 1996; Jansen-Verbeke, 1999; Kerstetter et al., 1998), maritime heritage (Smith, 2001), rural heritage (Prideaux \& Kininmont, 1999), local heritage (Teo \& Yeoh, 1997), culinary heritage (Reynolds, 1994; Romagnoli, 1995), dark tourism (Strange \& Kempa, 2003), 
ethnic heritage (Moscardo \& Pearce, 1999) and human heritage (Simic, 1994). It is argued here that this 'over-specification' may lead to confusion in the understanding of heritage tourism and to unnecessary over complication (if heritage tourism itself is to be regarded as a subgroup).

In this paper, tourist visitation patterns are examined from the viewpoint of the need to explore the link between individual and site. This approach is established on the body of theoretical literature which emphasises that different people experience heritage artefacts as well as heritage spaces differently due to their constructed symbolic meaning (e.g. Howard, 2003; Lowenthal, 1998). A question will be asked as to whether it is simply what the tourists look at, or the meaning they ascribe to it. With this in mind, three working approaches to 'heritage tourism' are first presented. The first stance is to regard heritage tourism as tourists located at heritage sites, with little emphasis on the actual tourists and their visitation patterns (e.g. Cheung, 1999; Cossons, 1989; Garrod \& Fyall, 2000). This means that all tourists who enter a space categorised as 'heritage' are seen as heritage tourists or taken to be engaged in heritage-related activities, even if they are not aware that the place being visited is a heritage site or have not observed the artefacts presented (the same argument was made by McKercher and du Cros (2002) in relation to ecotourism).

The second approach goes one stage further and emphasises the tourists rather than the site attributes (Swarbrooke, 1993). This approach focuses upon the tourist motivations to visit the site, primarily emphasising a willingness to learn and be involved in an educational experience because of the historic attributes of the site. Other studies highlighted religious motivation (among others) for a visit to heritage sacred sites (Graham \& Murray, 1997; Shackley, 2001). However, it is argued that this approach still does not get to the heart of the phenomenon, namely heritage. This approach could be useful for defining historic tourism, but does not give sufficient grounds to identify heritage tourism as an actual subgroup of tourism, distinct from historical tourism, cultural tourism or educational tourism.

An approach that examines visitation patterns in light of tourist perceptions of a site relative to their own heritage (before, during and after the visit) may be one way of meaningfully distinguishing heritage tourism. This approach is based on interaction between the tourist and the site attributes. This approach attempts to highlight the point that the meaning the tourists ascribe to what they see is of importance to a better understanding of heritage tourism. This is because tourism, in essence, is a social phenomenon taking place at a specific location, and to understand it both the site attributes and the visitors must be considered. Trying to understand tourism by examining site attributes alone is equivalent to examining a social phenomenon without discussing the individuals involved in the activity.

The following definition of heritage tourism attempts to integrate the three approaches described above (adapted from Poria, 2001a, 2001b and Poria et al., 2000, 2003):

A subgroup of tourism, in which the main motivation (demonstrated by the tourists' visitation patterns) for visiting a place is based on the heritage characteristics of the place (demonstrated by the site's attributes) 
according to the tourists' perception of their own heritage (demonstrated by the perceived link between the individual and the site - the tourists' perception of the site).

The crucial issue that differentiates the above definition from others is that it is the perception of site attributes rather than site attributes per se that are important. Such perceptions are key, because of their influence on tourist visitation patterns and their role in determining tourist views of a site in terms of it being part of their own heritage.

To illustrate the differences between these three approaches, the complexity of heritage tourism is discussed. The first approach includes all tourists who visit a site with heritage attributes classifying it under 'heritage tourism'. The second includes tourists who are aware of the heritage attributes of the site. In contrast, Poria et al. $(2000,2003,2004)$, when considering the phenomenon of 'heritage tourism', include only tourists who are motivated by the heritage attributes of the site and who consider the site to be part of their own heritage. It is argued that distinguishing between such groups of tourists may lead to a better understanding of tourism in general and heritage tourism in particular. This is due to the fact that tourist perceptions of a site relative to their own heritage are considered significantly to influence their visitation patterns.

It is argued here that the findings of different studies that focus on tourist perceptions of the site relative to their own heritage have implications for the management of heritage attractions as well as for theory development. The concept put forward is that the link between the individual (the tourist) and the site (the heritage presented) lies at the heart of understanding heritage tourism (as well as other tourism subgroups). If accepted, this concept, which has already been identified in theoretical studies, could lead to segmentation of tourists visiting heritage sites in order to better reflect tourist interests.

\section{Research Implementation}

As the research implementations of these studies have been described in previous studies (Poria et al., 2003, 2004), only those details important to the current paper are included here. One of the key attributes of the study's location was that it presents a diversity of tourists visiting heritage and historic places who perceive them differently relative to their own heritage. In this context, Israel is a highly suitable location as it contains, in a relatively small area, numerous heritage sites that would seem to relate differently to different individuals (Akhtar, 2000; Schiller, 1992). Modern Israel covers most of the biblical Holy Land, as well as some locations associated with Muhammad. Israel is also tied strongly to Jewish communities around the world and is part of the Zionist heritage. It was recognised from the outset that the choice of Israel would result in a study of places associated with the Bible and the history of Israel.

Cultural heritage sites can be classified in a number of ways (e.g. McKercher \& du Cros, 2002; Prentice, 1994; Timothy \& Boyd, 2003). Moreover, there are currently typologies of specific heritage attractions such as museums (Timothy \& Boyd, 2003), war attractions (e.g. Smith, 1996) or scared places 
(Shackley, 2001). The aforementioned could serve as a basis for the selection of the sites in this study. Here a judgemental sampling method was used in an attempt to choose sites that differ from each other in terms of their attributes to allow generalisation of the findings. For the first line of studies, the sites chosen for examination of tourist visitation patterns before, during and after the visit were the Western Wall and Massada. These sites were chosen due to their differences in terms of heritage. It was felt that they represented two types of heritage attractions. The Western Wall is a site that has, at its very heart, history that may be linked to its various visitors in different ways and for different reasons. To some, the heritage portrayed is perceived as highly linked to their identity, while for others it is not. Massada is an example of a site that provides its visitors with more than just a heritage experience (e.g. the view from the site, a visit to the desert area). Moreover, for this site, while the history presented may be perceived differently by different tourists, it is not strongly linked to any tourists' own heritage. It was thought that the selection of these two sites would allow generalisations of the findings and would better support the concept that tourist perceptions should be taken into account.

The Western Wall is, in fact, a very small area. The actual length of the wall accessible to the public is just $60 \mathrm{~m}$. The Western Wall (Ha-Kotel Ha-Ma'aravi in Hebrew) is the most important religious site for Jews and also has historic significance in that it is believed to be part of the original Temple. In addition, the Western Wall is associated with Israel's victory in the Six-Day War (1967), which for Zionists symbolises the existence of an independent Jewish state (Aner et al., 1981). The Western Wall also has Christian religious relevance, as Jesus stood there and prophesied the downfall of the Temple, criticising its management and how religion was being practised (Schiller, 1992).

It is argued that the Western Wall is also highly appropriate for the purposes of this research due to the site's other attributes. First, it is in close proximity to other attractions in Jerusalem which draw different groups of tourists (e.g. the Church of the Holy Sepulchre, Via Dolorosa, Yad Vashem). Second, there is no other feature of the area of the site itself that might influence visitation patterns (a factor that is not true of some other heritage attractions, such as Massada). Third, entrance is open to all (unlike other sites with a religious orientation in Jerusalem such as Al-Haram al-Sharif). Fourth, there is no entrance fee (as for some other heritage sites). Owing to this combination of factors, the site is visited by a variety of tourists who may approach its history in different ways.

Massada was chosen because its attributes are different from those of the Western Wall. Massada is a historic site per se and a site presenting history that some visitors perceive to be part of their own heritage. However, in contrast to the Western Wall, Massada, as well as presenting artefacts, provides visitors with a spectacular view of the desert, the Dead Sea and Jordan. The site is famous for its role in the Jewish revolt against the Romans (in AD 70), where it was the last pocket of Zealot resistance. The rebels decided not to surrender, but to kill each other so as not to be enslaved by the Romans and made to follow their religion (Mehling, 1987). Because of its history, the site 
has symbolic meaning and is commonly involved in the political discourse of today's modern Israel. Unlike the Western Wall, it is not located relatively close to other sites. Massada lies in the south of Israel, and is about threehours drive time from Tel Aviv, suggesting that visitors will not come to the site 'by accident'. There is also an entrance fee and, whereas a visit to the Western Wall may take less than 10 minutes, the actual length of a visit to Massada is commonly two to four hours.

\section{Investigating tourists' decisions regarding sites to visit}

In the second line of study, tourist decisions regarding which heritage sites to visit and how decisions are linked to their perceptions of the sites were clarified. For the purpose of this study, 10 venues in Israel were selected. Places were chosen that could be linked to tourists for various reasons. Some of the sites are well known for their link with religious events (e.g. the Western Wall, the Church of the Holy Sepulchre, Dome of the Rock, the Sea of Galilee). Other sites are famous for their connection with Jewish history and the Holocaust in particular (e.g. Beth Hatefutsoth, Yad Vashem). Some sites relate to recent events (e.g. Rabin's grave), while others relate to the earliest periods in human history. Sites relating to Judaism (e.g. the Western Wall), Christianity (e.g. the Church of the Holy Sepulchre) and Islam (e.g. Al-Aqsa Mosque) were intentionally included. As well as being heritage attractions, some of the sites have other aspects that attract tourists. For example, the Sea of Galilee is also a famous leisure spot in Israel, where people enjoy the scenery of the lake and even take part in sporting activities. Likewise, Massada, as well as having a place in Jewish history, offers visitors magnificent scenery. The sites were also chosen based on their distance from each other. Some of the sites are between one and three hours from Jerusalem (e.g. Massada, the Sea of Galilee), while some are located only a few of minutes walk from each other (the Western Wall, the Church of the Holy Sepulchre, Al-Aqsa Mosque, Dome of the Rock). It has to be recognised at this stage that some of the sites (although not mentioned in the sacred books, e.g. Eilat, Yad Vashem) may be considered religious or sacred as they are located in the Holy Land.

The research tool was a structured questionnaire implemented through faceto-face interviews. It was decided to interview international tourists after they had completed their visit to Israel. The interviews were conducted in the main Israeli airport while the tourists were waiting for their flights as this provided the diversity of tourists necessary for the research. The objective of the sampling strategy chosen (a theoretical sample) was not to achieve a representative sample of all international tourists visiting the sites, but to include a diversity of tourists. Such a research strategy, which aims at finding diversity rather than representing the population, could benefit the generalisation of the findings. The timing of the fieldwork was also planned so as to give maximum diversity of respondents.

The population was international tourists leaving Israel through Ben-Gurion Airport who were able to speak and understand English and were over the age of 15 (as at this age cognitive abilities are considered to be stable: Apter et al., 1998). Confining the population to international tourists was based on the 
assumption that there is greater diversity among this population than among the local population (particularly in the context of the sites investigated). Interviewing tourists as they left Israel meant that memories of their visit were relatively fresh.

Every $n$th tourist was approached while waiting for their flight (interviewers were asked not to approach participants in the duty-free shops). The value of $n$ was determined by factors such as the number of interviewers, the number of flights departing in a certain time period, the number of tourists waiting for a flight and the time remaining to flight departure. Before inclusion in the sample, the interviewees were asked to confirm whether or not they were tourists. (The participants were first asked if they were tourists to Israel and if they had stayed in Israel for more than 24 hours.) Then, the tourists were asked if they had had a chance to visit different places in Israel. Only those answering in the affirmative were included. The interviews were conducted by five students who had been chosen by one of the authors.

A feasibility study took place in December 1999, and then at the beginning of April 2000, the pilot study was conducted. The main study took place between April and May 2000 (this was done to avoid religious holidays and a Papal visit which may have had an influence on the diversity of tourists). Almost 400 (398) interviews were conducted. Approximately $15 \%$ of respondents asked not to participate in the study, generally stating that they were tired or working. The interviews took place during the day or at night, on weekdays and weekends, usually taking about 20 minutes. A small, token incentive was given to interviewees at the end of the interview.

\section{Establishing the research tool}

A quantitative research approach was applied in this study. To address the research question dealing with tourist visitation patterns before, during and after the visit in the context of the Western Wall and Massada, it was necessary to investigate the relationship between tourist perceptions of a site relative to their own heritage and their visitation patterns. The visitation patterns before a visit included motivations for the visit and previous visits. It was decided to concentrate on motivating factors due to the crucial importance of this variable in understanding behaviour (Baloglu \& Uysal, 1996; Crompton, 1979). Behaviour during the visit concentrated on actions (e.g. purchasing souvenirs, length of stay) and perceptions of the visit as an emotional experience. Satisfaction from the visit was explored - a factor associated with expectations as well as the actual on-site experience. Furthermore, differences in the level of satisfaction based on the variables studied may be useful in distinguishing between different types of tourists. Behaviour after the visit included intention to revisit (whether or not an entrance fee is charged), as well as willingness to recommend a friend to visit. As the literature suggests, these two patterns of behaviour are associated with consumer perceptions of a certain experience and can provide a basis for understanding tourist behaviour (Murphy, 2001). To address the tourist visitation patterns to the 10 different sites (the second line of study described in this paper), the tourists were asked about their perception of the sites relative to their own heritage and whether they had decided to visit the site. 
The questionnaire itself comprised several sections. After a short introduction, questions dealing with tourist visitation patterns to the 10 sites were posed. This was followed by a series of questions about the Western Wall and Massada (only if the tourists had visited the sites). At the end of the interview, the tourists were asked several questions about their personal characteristics and were thanked for their participation.

\section{The analysis}

The findings are based on differences among groups. A factor analysis (FA) technique was also used to explore interrelationships among the responses. In this research, principal-component analysis was used, because of its attribute as the 'first step in FA where it reveals a great deal about the probable number and nature of factors' (Tabachnick \& Fidell, 1996: 664). Then, oblique rotation was conducted because of the assumption that the actual factors are related to each other (with the assumption behind orthogonal rotation being that the factors are not related).

\section{Description of the sample}

The entire sample consisted of 398 participants, of whom 304 (77.6\%) and 136 $(34.2 \%)$ had visited the Western Wall and Massada respectively during their present visit. The gender distribution for the entire sample was $61.8 \%$ male and $38.2 \%$ female. Of those who had visited the Western Wall, 57.6\% were male and $42.4 \%$ female. For Massada, the figures were $58.8 \%$ male and $41.2 \%$ female. This unequal ratio of men to women could be due to the presence of business travelers in the sample, who were more likely to be men. The mode age group was 20-29 among the visitors to both Massada and the Western Wall. Of those who visited the Western Wall, 24.7\% (75) were Jewish and 64.8\% Christian (197). A further 8.7\% identified themselves as Muslims, other or no affiliation. In the context of Massada, 19.9\% were Jewish (27), 75\% Christians (102) and 5.1\% (7) identified themselves as Muslim, other or no affiliation.

\section{Findings}

The findings presented are divided into two sections. First, the tourist visitation patterns (before, during and after the visit) to the two sites will be considered. In the second section, the tourist decisions regarding which site to visit is examined. As this study produced a plethora of findings, it was decided to present only those which emphasised the core topic of this study, namely that tourist perceptions of a site relative to their own heritage is a key factor in understanding tourist behaviour in heritage settings. As such no analysis is presented on the tourist behaviours relative to their personal characteristics, although the link between these two notions is later discussed.

\section{Tourist visitation patterns to the two sites}

As illustrated here, the tourist perceptions of a site were linked to the visitation patterns for the two sites chosen. First the tourist perceptions of the sites relative to their own heritage are presented in Tables 1 and 2. 
Table 1 Tourist perceptions of the Western Wall relative to their own heritage

\begin{tabular}{|l|c|c|c|c|c|c||}
\hline \hline $\boldsymbol{0}$ & $\mathbf{1}$ & $\mathbf{2}$ & $\mathbf{3}$ & $\mathbf{4}$ & $\mathbf{5}$ & $\mathbf{6}$ \\
\hline $26.3 \%$ & $5.9 \%$ & $9.9 \%$ & $10.5 \%$ & $9.9 \%$ & $9.5 \%$ & $28 \%$ \\
\hline
\end{tabular}

$0=$ The site is absolutely not part of my heritage.

$6=$ The site is absolutely part of my heritage.

As can be seen, the distribution of tourist perceptions is different for the two sites. The tables show how the site is perceived relative to the tourist's own heritage using a seven-point scale. In the context of the Western Wall (see Table 1), most tourists perceived it to be either part of their own heritage $(28 \%)$ or not $(26.3 \%)$, while in the context of Massada (see Table 2 ) most tourists did not perceive the site as being part of their own heritage (positively skewed).

The findings were supported by an additional five questions relating to tourist perceptions of the sites relative to their own heritage, with a Cronbach alpha greater than 0.8 . Together these results provide an important starting point for the analysis.

In connection with the period before the visit, the tourists were asked to comment (by stating their level of agreement) on statements dealing with their motivation to visit the site. The list of reasons was almost the same for both sites, except for including 'because there is no entrance fee to the site' for the Western Wall. The list of motivations for visiting the sites was grouped using factor analysis techniques. As can be seen from Table 3, three groups emerged. Based on Table 3 , it is suggested that there is a very clear distinction between the nature of the three constructs. The first component embodied reasons linked to tourist perceptions of the site as part of their own heritage. The second group of reasons has nothing to do with the content presented at the site and is linked to the site as a recreational place.

The third group of reasons is related to the attributes of the site as an historic place in general. Another way of distinguishing between these three groups is that the first factor is commonly linked to the tourists' emotional involvement 'with the heritage presented' and the third relates to the tourists' willingness to learn. The second group of reasons has nothing to do with the tourists' involvement with the site. This division suggests that the reasons for visiting can be divided into those reasons which are linked to the heart - the emotional experience - linked to the brain - the intention to learn - and not linked to the core of the site - the material subject matter presented. Another way to clarify this difference is by how the tourists observe the heritage presented. The tourists who came to learn and wanted to look at the heritage 'objectively' are one group. Those who wanted to be exposed to their own heritage are a second

Table 2 Tourist perceptions of Massada relative to their own heritage

\begin{tabular}{|l|c|c|c|c|c|c|}
\hline $\mathbf{0}$ & $\mathbf{1}$ & $\mathbf{2}$ & $\mathbf{3}$ & $\mathbf{4}$ & $\mathbf{5}$ & $\mathbf{6}$ \\
\hline $30.9 \%$ & $5.1 \%$ & $8.8 \%$ & $14 \%$ & $11 \%$ & $14.7 \%$ & $15.4 \%$ \\
\hline
\end{tabular}

$0=$ The site is absolutely not part of my heritage.

$6=$ The site is absolutely part of my heritage. 
Table 3 Matrix of motivations to visit Massada

\begin{tabular}{|c|c|c|c|}
\hline \multirow[b]{2}{*}{ Tourist motivation* } & \multicolumn{3}{|c|}{ Components** } \\
\hline & $\begin{array}{l}\text { Heritage/ } \\
\text { emotional } \\
\text { experience }\end{array}$ & $\begin{array}{l}\text { Recreational } \\
\text { experience }\end{array}$ & $\begin{array}{c}\text { Cultural/ } \\
\text { educational } \\
\text { experience }\end{array}$ \\
\hline Initial Eigenvalues & 4.453 & 1.966 & 1.836 \\
\hline $\begin{array}{l}\text { Because you felt a sense of belonging } \\
\text { to the site }\end{array}$ & 0.869 & & \\
\hline Because it is part of your own heritage & 0.826 & & \\
\hline $\begin{array}{l}\text { Because you wanted to feel } \\
\text { emotionally involved }\end{array}$ & 0.764 & & \\
\hline Because you wanted to pray there & 0.688 & & \\
\hline Because of its religious characteristics & 0.675 & & \\
\hline $\begin{array}{l}\text { Because you thought it was important } \\
\text { to visit the site }\end{array}$ & 0.512 & & 0.499 \\
\hline $\begin{array}{l}\text { Because you felt obliged to visit the } \\
\text { site }\end{array}$ & 0.503 & & \\
\hline $\begin{array}{l}\text { Because you felt you should visit the } \\
\text { site }\end{array}$ & 0.500 & & 0.436 \\
\hline $\begin{array}{l}\text { Because you wanted to learn about the } \\
\text { site }\end{array}$ & & & 0.778 \\
\hline Because of its historic background & & & 0.662 \\
\hline $\begin{array}{l}\text { Because it is a world-famous site that } \\
\text { you had to see once in your life }\end{array}$ & & & 0.662 \\
\hline $\begin{array}{l}\text { Because of the physical nature of the } \\
\text { site }\end{array}$ & & & 0.453 \\
\hline $\begin{array}{l}\text { Because you wanted to have some } \\
\text { entertainment }\end{array}$ & & 0.733 & \\
\hline Because you wanted to have a day out & & 0.725 & \\
\hline $\begin{array}{l}\text { Because it was on your way to another } \\
\text { site }\end{array}$ & & 0.620 & \\
\hline Because you wanted to relax & & 0.576 & \\
\hline
\end{tabular}

Extraction method: Principal component analysis

Rotation method: Oblimin with Kaiser normalisation

Rotation converged in eight iterations

*The highest factor each motivation was loaded on is highlighted.

**The total variance explained by factor one is $27.83 \%$, by factor two is $12.29 \%$, by factor three is $11.48 \%$.

group. For them, the heritage was not something objective to look at, but a symbol for something relating to their own heritage. Finally, for the others this was something to glance at with no involvement at all.

Only the tourist motivations for visiting Massada are presented, as the same patterns were found for the Western Wall. It was decided to present the results in the context of Massada to emphasise that such findings were also found at a site not perceived by most of the tourists as 'absolutely part of their own 
Table 4 Pearson correlations between tourist perceptions and motivations

\begin{tabular}{||c|c|c|c|}
\hline \hline & $\begin{array}{c}\text { Heritage } \\
\text { motivation }\end{array}$ & $\begin{array}{c}\text { Recreation } \\
\text { motivation }\end{array}$ & $\begin{array}{c}\text { Learning } \\
\text { motivation }\end{array}$ \\
\hline $\begin{array}{c}\text { Tourist perceptions } \\
\text { of Massada } \\
\text { relative to their } \\
\text { own heritage }\end{array}$ & $0.571^{* *}$ & $0.149^{*}$ & $0.758^{* *}$ \\
\hline $\begin{array}{l}\text { Tourist perceptions } \\
\text { of the Western } \\
\begin{array}{l}\text { Wall relative to } \\
\text { their own } \\
\text { heritage }\end{array}\end{array}$ & $0.804^{* *}$ & -0.046 & $0.132^{*}$ \\
\hline \hline
\end{tabular}

*Correlation is significant at the 0.05 level (1-tailed).

** Correlation is significant at the 0.001 level (1-tailed).

heritage'. The correlation between the tourist perceptions of the sites and their motivation to visit was explored based on the results of the factor analysis (in Table 3). As can be seen from Table 4, there is a direct link between the two concepts for both sites. This again emphasises the importance of the tourist perceptions. This suggests, for example, that the more the tourists perceive the site as part of their own heritage, the more motivated they are to visit the site and to be emotionally involved. This is discussed later and has potential implications for heritage site management.

Another aspect that was subject to investigation was the number of times tourists had visited the site in the past. For both the Western Wall and Massada, the tourist perceptions were an indicator of previous visits. For example, in the context of Massada, there was a difference in terms of previous visits (based on a Tukey test; $p<0.1$ ) between those who did not perceive the site to be part of their own heritage ( 0.326 visits per tourist) and those who did ( 0.780 visits per tourist). A likely explanation for this is that those tourists who visit a site that is part of their own heritage will be interested in visiting the site more than once because of the emotional experience involved. Those tourists who do not consider a site as part of their own heritage may just want to see the site, and for them one visit is sufficient.

The tourists were also asked questions about their actual visit. In the context of the Western Wall, a pattern emerged relative to the tourists' length of stay at the site. If a site was perceived by the tourists to be part of their own heritage, they were likely to stay longer. This may be due to their desire to experience something not sought by those who do not perceive the site to be part of their own heritage. Another explanation may be that the tourists actually behave differently (e.g. in the context of the Western Wall, they may write a note or pray), leading them to spend more time at the site.

Another difference found in the context of the Western Wall was linked to the interpretation methods used at the site. Among those tourists who perceived the site as part of their own heritage, only $31.8 \%$ used interpretation methods, while $62.5 \%$ of those who absolutely did not perceive the site to be part of their own heritage used them. This may be because tourists who consider the site to be part of their own heritage are more aware of the site's 
history, or they may feel less need to learn while visiting the site (particularly if they had visited the site previously). In the context of Massada, almost no differences were found relative to the visitation patterns at the site. This may be due to the fact that at Massada most of the visitors come in organised groups in which they have less freedom to act as they might if on their own.

Differences were also found in the tourists' perception of the visit. In Table 5 the tourist perceptions of the visit in the context of Massada are presented. For analysis purposes, the participants were classified in three groups: those who do not perceive the site to be part of their own heritage (Group A, who answered 0 and 1); those who perceive the site to be absolutely part of their own heritage (Group C, who answered 5 and 6); and those who fall in-between (Group B, who answered 2, 3 or 4). The same pattern was found in the context of the Western Wall.

The results suggest both modest and relatively high positive relationships between tourist perceptions of the site as part of their own heritage and other aspects of their visit. It appears that the more the tourists consider the site to be part of their heritage, the more they regard the visit as an emotional experience. The differences described here suggest that tourists visiting

Table 5 Perception of site and perception of visit

\begin{tabular}{||l|c|c|c|c|c||}
\hline Perception of visit & \multicolumn{5}{|c|}{ Perception of site } \\
\hline & $\begin{array}{c}\text { Group I } \\
\text { Tourist } \\
\text { perceptions }\end{array}$ & Mean & $\begin{array}{c}\text { Group II } \\
\text { Tourist } \\
\text { perceptions }\end{array}$ & Mean & Significance \\
\hline $\begin{array}{l}\text { The visit to the site } \\
\text { contributed to } \\
\text { your education }\end{array}$ & \multicolumn{4}{|c||}{ No significant difference at 0.1 (Scheffe test) } \\
\hline $\begin{array}{l}\text { The visit to the site } \\
\text { moved you } \\
\text { emotionally }\end{array}$ & A & 2.898 & C & 4.317 & 0.001 \\
\hline $\begin{array}{l}\text { During the visit } \\
\text { you felt that } \\
\text { part of your } \\
\text { own heritage } \\
\text { was displayed }\end{array}$ & A & 0.489 & B & 2.173 & 0.000 \\
\hline \multicolumn{1}{|c|}{} & B & 0.489 & C & 3.878 & 0.000 \\
\hline $\begin{array}{l}\text { The visit to the site } \\
\text { made you feel } \\
\text { proud }\end{array}$ & A & 1.142 & C & 3.585 & 0.000 \\
\hline & B & 1.937 & C & 3.585 & 0.001 \\
\hline$n=136$ & B & 2.173 & C & 3.878 & 0.000 \\
\hline
\end{tabular}

Note: $\mathrm{A}=$ Not part of heritage $(n=49) ; \mathrm{B}=$ Somewhat part of heritage $(n=46)$; $\mathrm{C}=$ Definitely part of heritage $(n=41)$. 
heritage sites are exposed to different experiences, based on the relationship between the site attributes (e.g. the heritage presented) and the tourists (e.g. their perception of the heritage presented).

Participants were also asked questions about their future intention to visit the site and their intention to recommend a visit to their friends. The tourists were given a 0 to 6 scale, where 0 represents 'I completely disagree' and 6 'I completely agree'. Almost no differences were found between tourists relative to their intention to recommend a visit to their friends. The results indicate that the more the tourists perceive a site to be part of their own heritage, the more they would like to visit the site in the future. Both in the context of Massada and the Western Wall, more differences were found when participants were referring to themselves than when referring to friends.

For example, in the context of Massada the respondents illustrated a very high intention to recommend a visit to their friends (the overall average was 5.5; those not perceiving the site to be part of their own heritage averaged 5.4 , and those who did perceive the site to be part of their own heritage averaged 5.6). One possible reason for this may be because respondents have a low level of certainty when speaking for their friends. However, based on the Tukey test, clear differences $(p<0.1)$ were found in the response to the question dealing with the tourists themselves. The difference was clear between those who perceive the site to be part of their own heritage (4.3) and those who do not (3.4). This suggests that the tourists were exposed to different experiences. One type of experience (i.e. the heritage experience) may cause tourists to show a greater intention to revisit the site than another (i.e. the cultural/historical experience).

\section{Tourist decisions regarding which heritage site to visit}

An attempt was made in the second line of study to clarify tourist decisions of which heritage site to visit in a space where there are many heritage sites. The starting point for the analysis was tourist perceptions of the 10 sites in relation to their own heritage. These results are reported in Table 6. Respondents were provided with a scale of 0 to 6 (where 0 indicates that 'the site is absolutely not part of my heritage' and 6 that 'the site is absolutely part of my heritage'). For analysis purposes, the participants were put into three groups (as in Table 5). The number of participants for each site is different, because those who were not familiar with a site were eliminated, and this number is different for each site.

In Table 7 the portion of respondents who had visited a site from each group is presented. As can be seen, significant differences were found when comparing the visitation patterns relative to tourist perceptions for all sites except the Western Wall. This means that tourist perceptions of a site relative to their own heritage are linked to their decision to visit it. Because it is a world-famous site, the Western Wall was visited by the vast majority of the tourists (97.1\%), and in this case no differences were found.

These results suggest that tourist decisions whether to choose to visit a site or not, are closely linked to their perception of the site relative to their own heritage. 
Table 6 Tourist perceptions of the site relative to their own heritage

\begin{tabular}{||l|c|c|c|c||}
\hline The site & $\begin{array}{c}\text { Number of tourists } \\
\text { aware of the site }\end{array}$ & $\begin{array}{c}\text { Group A } \\
(\%)\end{array}$ & $\begin{array}{c}\text { Group B } \\
\text { (\%) }\end{array}$ & $\begin{array}{c}\text { Group C } \\
\text { (\%) }\end{array}$ \\
\hline Eilat & $n=292(81.7 \%)^{*}$ & 81.2 & 15.1 & 3.8 \\
\hline $\begin{array}{l}\text { Beth } \\
\text { Hatefutsoth }\end{array}$ & $n=76(21.2 \%)^{*}$ & 28.9 & 31.6 & 39.5 \\
\hline Western Wall & $n=347(97.1 \%)^{*}$ & 31.1 & 28.8 & 40.1 \\
\hline $\begin{array}{l}\text { The Holy } \\
\text { Sepulchre }\end{array}$ & $n=291(81.5 \%)^{*}$ & 32.6 & 23.0 & 44.3 \\
\hline $\begin{array}{l}\text { Yad Vashem } \\
\text { Dome of the } \\
\text { Rock }\end{array}$ & $n=217(60.7 \%)^{*}$ & 21.2 & 25.3 & 53.5 \\
\hline $\begin{array}{l}\text { Al-Aqsa } \\
\text { Mosque }\end{array}$ & $n=229(64.1 \%)^{*}$ & 71.2 & 26.5 & 16.6 \\
\hline Massada & $n=303(84.8 \%)^{*}$ & 37.0 & 30.4 & 32.7 \\
\hline Rabin's grave & $n=198(55.4 \%)^{*}$ & 40.9 & 37.4 & 21.7 \\
\hline Sea of Galilee & $n=344(96.3 \%)^{*}$ & 23.3 & 23.8 & 52.9 \\
\hline
\end{tabular}

*Percentage of tourists aware of the site relative to all those who had the chance to visit different places in Israel $(n=357)$.

Note: $\mathrm{A}=$ Not part of heritage; $\mathrm{B}=$ Somewhat part of heritage; $\mathrm{C}=$ Definitely part of heritage.

When comparing tourists on their first visit and those who had previously visited Israel, some interesting results emerged. It was found that tourist perceptions of the Western Wall were more important for those whose present visit was their first. Nevertheless differences were also found among those who had already visited Israel, suggesting that the preference to visit sites linked to their heritage was stronger than the desire to be exposed to new experiences.

\section{Discussion}

The results of these studies clearly indicate that tourist behaviours at a heritage site (motivation to visit a site, behaviour at that site, perception of the visit and potential behaviour in the future) as well as their decision regarding which heritage sites to visit are all linked to the perception of a site as part of their own heritage. These relationships suggest that tourist perceptions of a site as part of their own heritage is, in turn, at the core of 'heritage tourism'. It is suggested that those tourists who do perceive a site to be part of their own heritage form the basis of the phenomenon called heritage tourism and can be distinguished from other tourists based on their behaviour. From this it follows that 'heritage tourism' should not include tourists who are visiting a site 'just because it's there' or those who are primarily motivated by a desire to learn, in the sense that they see a site as just another educational or cultural feature. 
Table 7 Proportion of tourists visiting related to heritage links

\begin{tabular}{|c|c|c|c|c|c|c|}
\hline & $\begin{array}{l}\text { Group } I \\
(\%)\end{array}$ & $\begin{array}{c}\text { Group } I I \\
(\%)\end{array}$ & $\begin{array}{c}\text { Group III } \\
(\%)\end{array}$ & One-way ANOVA & $\begin{array}{l}\text { Significant differences } \\
\text { found between: }\end{array}$ & Scheffe test \\
\hline Eilat $(n=292)$ & 55.2 & 84 & 72.7 & $\begin{array}{l}\mathrm{F}=7.065, \mathrm{Df}=2.289 \\
\mathrm{Sig}=0.01^{* *}\end{array}$ & Group A and Group B & $0.001^{* *}$ \\
\hline Beth Hatefutsoth $(n=76)$ & 27.2 & 62.5 & 86.6 & $\begin{array}{l}\mathrm{F}=12.150, \mathrm{Df}=2.73 \\
\mathrm{Sig}=0.000^{* * *}\end{array}$ & $\begin{array}{l}\text { Group A and Group B } \\
\text { Group A and Group C }\end{array}$ & $\begin{array}{l}0.025^{* *} \\
0.000^{* * *}\end{array}$ \\
\hline Western Wall $(n=347)$ & 95.3 & 96 & 97.1 & $\begin{array}{l}F=0.269, D f=2.344 \\
\text { Sig }=0.764\end{array}$ & No differences found & \\
\hline $\begin{array}{l}\text { The Holy Sepulchre } \\
\quad(n=291)\end{array}$ & 62.1 & 85 & 96.1 & $\begin{array}{l}\mathrm{F}=25.797, \mathrm{Df}=2.288 \\
\mathrm{Sig}=0.000^{* * *}\end{array}$ & $\begin{array}{l}\text { Group A and Group B } \\
\text { Group A and Group C }\end{array}$ & $\begin{array}{l}0.000^{* * *} \\
0.000^{* * *}\end{array}$ \\
\hline Yad Vashem $(n=217)$ & 50 & 70.9 & 78.4 & $\begin{array}{l}\mathrm{F}=6.721, \mathrm{Df}=2.214 \\
\mathrm{Sig}=0.001^{* * *}\end{array}$ & Group A and Group C & $0.001^{* *}$ \\
\hline $\begin{array}{l}\text { Dome of the Rock } \\
\quad(n=302)\end{array}$ & 59.8 & 75 & 82 & $\begin{array}{l}\mathrm{F}=5.858, \mathrm{Df}=2.299 \\
\mathrm{Sig}=0.003^{* *}\end{array}$ & Group A and Group C & $0.012^{* *}$ \\
\hline $\begin{array}{l}\text { Al-Aqsa Mosque } \\
(n=229)\end{array}$ & 54.6 & 70.8 & 88.8 & $\begin{array}{l}F=5.486, D f=2.226 \\
S i g=0.005^{* *}\end{array}$ & Group A and Group C & $0.017^{* *}$ \\
\hline Massada $(n=303)$ & 56.5 & 75 & 83.8 & $\begin{array}{l}\mathrm{F}=10.860, \mathrm{Df}=2.300 \\
\mathrm{Sig}=0.000^{* * *}\end{array}$ & $\begin{array}{l}\text { Group A and Group B } \\
\text { Group A and Group C }\end{array}$ & $\begin{array}{l}0.011^{* *} \\
0.000^{* * *}\end{array}$ \\
\hline Rabin's grave $(n=198)$ & 18.5 & 39.1 & 55.8 & $\begin{array}{l}\mathrm{F}=10.0830, \mathrm{Df}=2.195 \\
\mathrm{Sig}=0.000^{* * *}\end{array}$ & $\begin{array}{l}\text { Group A and Group B } \\
\text { Group A and Group C }\end{array}$ & $\begin{array}{l}0.020^{* *} \\
0.000^{* * *}\end{array}$ \\
\hline Sea of Galilee $(n=344)$ & 65 & 78 & 88.4 & $\begin{array}{l}\mathrm{F}=10.483, \mathrm{Df}=2.341 \\
\mathrm{Sig}=0.000^{* * *}\end{array}$ & Group A and Group C & $0.000^{* * *}$ \\
\hline
\end{tabular}


It is important to notice that almost no differences were found between the tourists' visitation patterns to Massada and the Western Wall, which further supports the key influence of tourist perceptions. Nevertheless, some differences found are attributed to the physical features of the site rather than its meaning in terms of heritage. In Massada there are self-guided trails which visitors usually follow, while the Western Wall is more of an open space with almost no formal interpretation. In addition, Massada is known for its spectacular beauty and as a vantage point from which the desert and the Dead Sea can be seen. These attributes should be taken into account when attempting to generalise the findings of this study.

The main aim of this research was to challenge the present approach in which heritage tourism is considered to be tourists in heritage places. This was done by exploring whether the relationship between tourists and a site could form the basis for understanding their behaviour. The findings of the studies reported here indicate that tourists (as well as other visitors to heritage sites) can be segmented based on their perception of a site relative to their own heritage (the way they see the heritage presented). As a link was found between tourist perceptions of the site relative to their own heritage and certain behaviours at two heritage sites which differ one from each other as well as in the tourists' decision of which heritage sites to visit provide validity to support the notion that tourist perceptions are at the core of understanding tourist behaviours at heritage settings.

The relationships explored in this study support the literature, which suggests that to understand behaviour relative to heritage exhibits, there is a need to investigate if the actual experience of the site evolves from the relationship between the individuals and the artifact or space (e.g. Uriely et al., 2002). In their attempt to define heritage tourism, Timothy and Boyd (2003) identified an ongoing debate about the nature of heritage tourism. There are currently two common approaches. The first emphasises the presence of the tourists in a certain space, while the second emphasises the link between the individual and the space. In the context of heritage tourism, the 'link' is argued to be tourist perceptions of the site relative to their own heritage. Based on the findings of these studies, it is suggested that tourist perceptions of a site relative to their own heritage plays a key role in understanding tourist behaviour at those sites. As such, it is suggested that tourist perceptions of the site differentiates heritage tourism from other subgroups of tourism identified in the literature (e.g. cultural tourism, education tourism).

The findings of this study should raise the question of whether this interaction between an individual and a site should lie at the heart of our understanding of tourism as a whole. Currently tourism subgroups emerge based on identification of the presence of tourists in certain spaces. There may be a place for a different approach to classifying tourism subgroups. For example, the findings of this study suggest that some of the tourists came to be emotionally involved and to feel they had assigned personal meaning to what they saw. The artefact presented for them was a symbol of something relevant for them. They wanted to be connected to their own heritage. Another group came to learn and be further educated about another heritage. They observed the heritage presented without personal emotional involvement. 
They wanted to understand what they saw better. Others still came without any specific motivation linked to the historic attributes of the site, they just observed. They did not assign personal meaning and were not involved in cognitive effort. For these tourists, the visit was an opportunity to be 'out there', at the site in question. These three groups may be relevant to other identified subgroups of tourism, or may provide a way to differentiate between individuals involved in tourist activities.

The classification of the visitors to heritage settings may provide better understanding of visitor behaviours at heritage sites. The segmentation suggested here is different from those based on the tourists' personal characteristics, the attributes of the site (e.g. Swarbrooke, 1993) or the relative importance of the visit to a particular site to the decision to visit the destination where the site is located (Silberberg, 1995). The classification suggested here is in line with scholars who highlight elements of the actual experience sought or gained. This segmentation is in line with, for example, Timothy (1997) who relates in his classification to the emotions visitors feel in relation to the heritage presented. Also, the segmentation of the cultural tourist presented by McKercher and $\mathrm{du}$ Cros (2002) emphasises the actual experience sought on site (as well as the importance of cultural tourism in the decision to visit a destination). However, as opposed to the latter, here there is no call to classify the actual experience as 'deep' or 'shallow' or to capture the importance of the visit to a particular site in the decision to visit a destination (McKercher \& du Cros, 2002: 140). Here a distinction was made between the interests of the visitor and the meaning assigned to the site. It is specifically mentioned here that for those who want to 'learn' (and do not perceive the site as part of their own heritage) or 'feel' (and do perceive the site as part of their own heritage) the visit may be 'deep'. Both those who want to learn and feel may be 'profound' and search for meaning, although a different one (Cohen, 2004). Nevertheless, it is not claimed that the relationship identified here between tourist perceptions and behaviours may not be found with other elements already used in the literature to classify visitors to heritage settings (e.g. emotions, the importance of the site to the decision to visit a destination).

It should be recognised that tourism literature has already noted differentiation between visitors to heritage sites. Moscardo and Pearce (1999), for example, differentiated between visitors based on their desire for contact with the ethnic people, interest in learning and participation in traditional activities. Moscardo (1996) differentiated between mindful and mindless visitors based on their motivation for the visit (educational vs. entertainment/social). McIntosh (2004) differentiated based on tourist approach to the local (Maori) culture. It is suggested based on the findings of the studies reported here that to understand those visitor behaviours at heritage settings, spaces which carry different meanings for different people and in which the visitor plays a key role in the understanding the site (Black, 2001; McIntosh \& Prentice, 1999), there is a need to explore the relationships between the visitor and the site (i.e. do the tourists perceive the site as part of their own heritage or not?).

The findings contribute to researchers and practitioners alike. Swarbrooke (2002) identified different ways to segment visitors to tourist attractions: geographic, demographic, psychographic and behaviouristic. Although the 
study recognises that visitors can be grouped based on their perception of the site (i.e. psychographic segmentation), it should be highlighted that the tourist perception is an abstract concept. The need to find a link between an abstract concept, which contributes to our theoretical understanding, and more recognisable variables, which are important to heritage site managers, has already been identified as crucial in heritage settings (Moscardo \& Pearce, 1999; Prentice et al., 1997). In the studies described in this paper, a relationship was found between the tourists based on their religious affiliation as well as their strength of religious belief (i.e. demographic segmentation), their approach towards the site (i.e. psychographic segmentation) and their behaviours on site (i.e. behaviouristic segmentation). The links between the tourist approach towards the site, their behaviours and personal characteristics provides managers with a tool to differentiate and target visitors using different market mixes. Heritage site managers need to take into account that in other heritage settings other demographic characteristics may be linked to the tourist perceptions of the site.

An outcome of this is that researchers should emphasise the links between the site and the visitor in their research. The investigation of these 'links' will provide a deeper understanding of tourist behaviours at heritage sites and other tourist attractions. The 'link' between the visitor and the site is key to understanding the tourist experience, which provides heritage site management the opportunity to become market-oriented at every level of operation and planning (Beeho \& Prentice, 1997).

If a link is found between the tourist perceptions and their personal characteristics, it may provide a management tool for those managing heritage places. Two such elements for which the findings of this study may have implications are discussed. It was identified here that tourists visit cultural heritage attractions for different reasons. This should influence the marketing of such places. For example, it may be more appropriate to target the market in different ways, rather than provide just a 'straight' translation of a marketing campaign when different target audiences exist (as is common for heritage sites nowadays). There may also be an argument for providing visitors with different interpretation while at the site. For example, instead of the usual pattern of guiding all tourists in the same way (e.g. the text of the audio tours the visitors is exposed to is identical, except for being translated), it may be better to provide different audiences with different experiences.

The results indicate that tourist perceptions are linked to their decision as to which heritage site to visit in a space in which several heritage attractions are available. This information may be relevant for those organising tours in historical areas, suggesting that the decision as to which heritage site or tourist attraction to visit should consider the tourist perception of the site. Those organising tours should consider their potential and actual consumers. This may be also relevant for the megamuseums in which a variety of exhibits are presented and the tourist cannot observe all exhibits in one day. It is argued here that such museums should offer different tours. For example, at the British Museum visitors from Egypt and Greece may be interested in viewing different sections of the museum. The aforementioned will result in interpretation and experiences that relate to the visitors' own frame of 
reference (McKercher \& du Cros, 2002). In addition, the findings suggest that visitors are interested in different experiences; some want to learn while others want to feel. Heritage managers should plan their interpretation in line with this finding. One form of interpretation should be provided for those who want to learn and another for those who 'seek to go beyond knowledge - to engage the senses and emotions of the visitor' (Black, 2001: 128).

Theoretical studies have suggested that those visiting heritage sites approach them differently, as heritage spaces are socially constructed. To conclude, in light of Howard's claim that 'heritage is for people, not just for a small minority of specialists' (2003: 33) and Lowenthal's argument (1998: 3) that 'never before have so many been so engaged with so many different pasts', it is argued here that there is a need to speak with all people and learn about their perceptions in order to provide visitors with a quality heritage experience. This may provide the opportunity for those whose heritage or interpretation of the heritage exhibits has been ignored (Graham et al., 2000) to experience heritage spaces rather than just visit them.

\section{Future Research}

Similar to other studies, this study suffers from a series of limitations, some of which may be overcome by future research. The study took place in Israel, and most of the sites are linked directly or indirectly with the Bible (although in the first line of study (e.g. Massada) and the second (e.g. Rabin's grave, Massada, Eilat, Beth Hatfutsoth and Yad Vashem) non-religious sites were also chosen. It may be that because the sites are located in the Holy Land, tourists consider them as religious sites. Future research should look at other sites not linked to visitors' religion.

This study explored different aspects of the tourists' behaviour. Future research could concentrate on other aspects not explored here (e.g. the theme of the interpretation, the overall interest in interpretation) to make a further contribution to cultural heritage managers. Further research may also investigate whether tourist perceptions of a site are linked to the expectations of a visit. Based on the findings, it is suggested that visitors may expect different benefits from their visit. Such a study may help those involved in heritage management better fulfill tourist expectations and provide them with an experience that will meet their needs. This, in turn, may lead to higher levels of satisfaction and more return visits. Further research could also explore the overall motivation of tourists for a visit as well as those who decided not to visit a heritage site. The findings of such studies can challenge the validity of the current findings (Prentice et al., 1997) and provide cultural heritage managers with insight as to which segment should receive the marketing budget.

In this study, a quantitative research approach was adopted. Additional work should be done by implementing qualitative research methods to shed light on issues not highlighted here, though crucial to the understanding of heritage tourism. For example, this might include investigating the role of other (non-heritage) activities important to the visitor experience of a heritage site or clarifying the emotions and the meanings assigned to the heritage exhibits relative to tourist behaviours. 


\section{Correspondence}

Any correspondence should be directed to Dr Yaniv Poria, School of Management, Department of Hotel and Tourism Management, Ben-Gurion University of the Negev, Beer-Sheva, Israel (yporia@som.bgu.ac.il).

\section{References}

Akhtar, S. (2000) Christians, Muslims, Jews living in disharmony. The Times Higher Educational Supplement 424, 22-23.

Alzua, A., O'Leary, J.T. and Morrison, A.M. (1998) Cultural and heritage tourism: Identifying niches for international travelers. The Journal of Tourism Studies 9 (2), 2-13.

Aner, Z., Ben-Dov, M. and Naor, M. (1981) The Western Wall. Givataim: Ministry of Defence (in Hebrew).

Apter, A., Hatab, J., Tyano, S. and Weizinan, A. (1998) Child and Adolescent Psychology. Tel Aviv: Dyonon Publishing (in Hebrew).

Baloglu, S. and Uysal, M. (1996) Market segments of push and pull motivations: A canonical correlation approach. International Journal of Contemporary Hospitality Management 8 (3), 32-38.

Beeho, A.J. and Prentice, R.C. (1997) Conceptualizing the experience of heritage tourists: A case study of New Lanark World Heritage Village. Tourism Management 18 (2), 75-87.

Black, G. (2001) Hows of concept design. In S. Drummond and I. Yeoman (eds) Quality Issues in Heritage Visitor Attractions (pp. 121-135). Oxford: Butterworth Heinemann.

Black, N.L. (1990) A model and methodology to assess change to heritage buildings. The Journal of Tourism Studies 1 (1), 15-23.

Chang, T.C., Milne, S., Fallan, D. and Pohlmann, C. (1996) Urban heritage tourism: The global-local nexus. Annals of Tourism Research 23 (2), 284-305.

Cheung, S.C.H. (1999) The meanings of a heritage trail in Hong Kong. Annals of Tourism Research 26, 570-588.

Cohen, E. (2004) Contemporary Tourism: Diversity and Change. Amsterdam: Elsevier.

Cossons, M. (1989) Heritage tourism: Trends and tribulations. Annals of Tourism Research 10, 192-194.

Crompton, J. (1979) Motivations for pleasure vacation. Annals of Tourism Research 6, $408-424$.

Edwards, J.A. and Coit, J.C.L. (1996) Mines and quarries: Industrial heritage tourism. Annals of Tourism Research 23, 341-363.

Garrod, B. and Fyall, A. (2000) Managing heritage tourism. Annals of Tourism Research 27, 682-708.

Gibson, C. and Hordman, D. (1998) Regenerating urban heritage for tourism. Managing Leisure 3 (1), 37-54.

Graham, B., Ashworth, G.J. and Tunbridge, J.E. (2000) A Geography of Heritage: Power, Culture and Economy. London: Arnold.

Graham, B. and Murray, M. (1997) The spiritual and the profane: The pilgrimage to Santigo de Compostela. Tourism Management 9, 44-62.

Howard, P. (2003) Heritage: Management, Interpretation, Identity. London: Continuum.

Hooper-Greenhill, E. (1994) Museums and their Visitors. London: Routledge.

Jansen-Verbeke, M. (1999) Industrial heritage: A nexus for sustainable tourism development. Tourism Geographies 1 (1), 70-85.

Keller, A. (1999) Jobs and the natural heritage in Scotland. Countryside Recreation 7 (1), 6.

Kerstetter, D., Confer, J. and Bricker, K. (1998) Industrial heritage attractions: Types and tourists. Journal of Travel and Tourism Marketing 7 (2), 91-104.

Kotler, P., Bowen, J. and Makens, J. (2003) Marketing for Hospitality and Tourism. Upper Saddle River, NJ: Prentice Hall.

Lowenthal, D. (1998) The Heritage Crusades and the Spoils of History. Cambridge: Cambridge University Press.

MacDonald, R. and Jolliffe, L. (2003) Cultural rural tourism: Evidence from Canada. Annals of Tourism Research 30 (2), 307-322. 
McIntosh, A.J. (2004) Tourists' appreciation of Maori culture in New Zealand. Tourism Management 25, 1-15.

McIntosh, A.J. and Prentice, R.C. (1999) Affirming authenticity: Consuming cultural heritage. Annals of Tourism Research 26 (3), 589-612.

McKercher, B. and du Cros, H. (2002) Cultural Tourism: The Partnership between Tourism and Cultural Heritage Management. New York: The Haworth Press.

Mehling, M. (1987) Jerusalem and the Holy Land. Oxford: Phaidon.

Moscardo, G. (1996) Mindful visitors: Heritage and tourism. Annals of Tourism Research 23 (2), 376-397.

Moscardo, G. and Pearce, P.L. (1999) Understanding ethnic tourists. Annals of Tourism Research 26 (2), 416-434.

Murphy, L. (2001) Exploring social interactions of backpackers. Annals of Tourism Research 28 (1), 50-67.

Poria, Y. (2001a) Challenging the present approach to heritage tourism: Is tourism to heritage places heritage tourism? Tourist Review 56 (1/2), 51-53.

Poria, Y. (2001b) The show must NOT go on. Tourism and Hospitality Research 3 (2), $115-119$.

Poria, Y., Butler, R. and Airey, D. (2000) Clarifying heritage tourism: A distinction between heritage tourism and tourism in historic place. Annals of Tourism Research 28 (4), 1047-1049.

Poria, Y., Butler, R. and Airey, D. (2001) Tourism subgroups: Do they exist? Tourism Today 1 (1), 14-22.

Poria, Y., Butler, R. and Airey, D. (2003) The core of heritage tourism: Distinguishing heritage tourists from tourists in heritage places. Annals of Tourism Research 30 (1), $238-254$.

Poria, Y., Butler, R. and Airey, D. (2004) How tourists decide which heritage site to visit? Tourism Review 59 (2), 12-16.

Prentice, R.C. (1994) Heritage: A key sector of the "new" tourism. Progress in Tourism, Recreation, and Hospitality Management 5, 309-324.

Prentice, R., Davies, A. and Beeho, A. (1997) Seeking generic motivations for visiting and not visiting museums and like cultural attractions. Museum Management and Curatorship 16 (1), 45-70.

Prideaux, B.R. and Kininmont, L.J. (1999) Tourism and heritage are not strangers: A study of opportunities for rural heritage museums to maximise tourism visitation. Journal of Travel Research 37 (3), 299-303.

Reynolds, P. (1994) Culinary heritage in the face of tourism. Progress in Tourism, Recreation and Hospitality Management 6, 189-194.

Romagnoli, G.F. (1995) Rome's Jewish quarter: A rich culinary heritage. Gourmet 55 (8), 52-55, 90-94.

Schiller, E. (1992) Guide to Christian Historical Sites and Holy Places in Israel. Jerusalem: Arial (in Hebrew).

Shackely, M. (2001) Sacred world heritage sites: Balancing meaning with management. Tourism Recreation Research 26 (1), 5-10.

Silberberg, T. (1995) Cultural tourism and business opportunities for museums and heritage sites. Tourism Management 16 (5), 361-365.

Simic, A. (1994) Evaluation of the natural and human heritage of Biokovo area. Acta Turistica 6 (2), 123-159.

Smith, V.L. (1996) War and its tourist attractions. In A. Pizam and Y. Mansfeld (eds) Tourism, Crime and International Security Issues (pp. 247-264). New York: Wiley.

Smith, H.D. (2001) The British Maritime Heritage. RGS-IBG Annual Conference, University of Plymouth, 2nd-5th January, 2001, p. 129.

Strange, C. and Kempa, M. (2003) Shades of dark tourism: Alcatraz and Robben Island. Annals of Tourism Research 30 (2), 386-405.

Swarbrooke, J. (1993) The future of heritage attractions. Insights 4, D15-D20.

Swarbrooke, J. (2002) The Development and Management of Visitor Attractions. Oxford: Butterworth Heinemann. 
Tabachnick, B.G. and Fidell, L.S. (1996) Using Multivariate Statistics. New York: Harper Collins College.

Teo, P. and Yeoh, B.S.A. (1997) Remaking local heritage for tourism. Annals of Tourism Research 24 (1), 192-213.

Timothy, D.J. (1997) Tourism and the personal heritage experience. Annals of Tourism Research 34, 751-754.

Timothy, D.J. and Boyd, S.W. (2003) Heritage Tourism. Harlow: Prentice Hall.

Uriely, N., Israeli, A.A. and Reichel, A. (2002) Heritage proximity and resident attitudes toward tourism development. Annals of Tourism Research 29 (3), 859-861. 